\title{
Need for Achievement: Competency-Based Testing and Its Normative Premises 1970-2000
}

\author{
Andreas Gelhard \\ University of Vienna, Austria
}

\begin{abstract}
Competency-based testing is part of a broader trend towards a psychologization of the pedagogical which is characteristic for the educational systems of the USA and Europe in the second halve of the 20th century. The article examines David C. McClelland's pathbreaking paper Testing for Competence Rather Than for "Intelligence" (1973) as an important testimony of this trend. McClelland's paper breaks down into two halves that rely on fundamentally different normative premises: on the one hand the political demand for social equality, on the other hand the economic demand for increased performance. Only the latter demand, which is formulated most forcefully in McClelland's book The Achieving Society (1961), can be considered as a crucial factor in determining the course of the recent reforms of the educational systems of the German-speaking world. A clear example of this can be seen in Franz E. Weinert's influential paper on Comparative Performance Measurement in Schools (2001).
\end{abstract}

Keywords: psychology, pedagogy, competency, testing, achievement

The concept of "competency", at least as implemented in the educational systems of the German-speaking world for almost two decades now, did not originate within pedagogic circles. It arose instead as part of a peculiar cooperation between academic psychology and professional business consultancy that occurred in the second half of the 20th century. David C. McClelland, who is widely acknowledged as father of the competency concept, perfectly embodies this combination: He taught psychology at Harvard University and was also a co-founder of McBer \& Company, a management consulting company.

All of this points to the need for warnings against the increasing economization of the educational system. Yet justified as I find these concerns, they run the danger of lapsing into oversimplification by ignoring an analysis of the new mechanisms of power that are installed with the aid of the competency concept. When these mechanisms are subjected to closer scrutiny, it becomes clear that the ostensible problem is no longer a linear economization of the educational system, but rather a psychologization of the pedagogical, which serves as a methodical basis for the new instruments of governance.

I'll limit my present examination of this theme to a few examples from the period between 1970 and 2000: David C. McClelland's trend-setting paper Testing for Competence Rather Than for “Intelligence”(1973), Franz E. Weinert's oft-cited paper on Comparative Performance Measurement in Schools (2001) and the expert report On the Development of National Educational Standards (2003) issued by an expert working group on behalf of the German Ministry for Education and Research. The focus of my remarks will remain on McClelland, however. ${ }^{1}$

\footnotetext{
Andreas Gelhard, Dr., Assistant professor, University of Vienna, Austria.

${ }^{1}$ For a more detailed examination of the history of competency-based testing cf. Gelhard, 2012.
} 


\section{McClelland's Thesis}

Any effort to summarize the fundamental traits of David C. McClelland's competency concept in just a few key principles must start with the core thesis of his paper from 1973. It offers up the following concise statement: "It is difficult, if not impossible, to find a human characteristic that cannot be modified by training or experience" (1973, p. 8).

This thesis is crucial to the introduction of a psychology-based competency concept into daily school practice. It is oriented directly against the widespread practice in 1970s America of using IQ tests to identify suitable students and job applicants, a practice based on the theory that intelligence is an innate mental disposition that could be tested but not trained.

Positing "competency" as the diametric antithesis to this, McClelland formulates that all decisive mental dispositions can not only be tested, but trained as well. As such, he (re)opens the field of psychological research to questions of education. In McClelland's view, the new test formats have already achieved an important goal "if they encourage educators to stop thinking only about selection and start thinking about evaluating educational progress" (p. 13).

I'll come back to this later. First I'd like to use McClelland's thesis to differentiate between the two complete different levels upon which his paper from 1973 introduced the term of "competency". This is necessary because the text breaks down-roughly speaking-into two halves pursuing entirely different normative premises: the political demand for social equality and the economic demand for increased performance.

\section{First Normative Principle: Social Equality}

Testing for Competence Rather Than for "Intelligence" merges the form of the academic treatise with the rhetoric of a political pamphlet. Anyone reading the paper for the first time will be astounded at the intensity with which McClelland denotes and questions the societal power of psychological tests. The opening sentences of his essay deserve to be cited in toto, as they very clearly illuminate McClelland's political motivations:

The testing movement in the United States has been a success, if one judges success by the usual American criteria of size, influence and profitability. Intelligence and aptitude tests are used nearly everywhere by schools, colleges, and employers. It is a sign of backwardness not to have test scores in the school records of children. The Educational Testing Service alone employs about 2,000 people, annually administers Scholastic Aptitude Tests to thousands of aspirants to college, and makes enough money to support a large basic research operation. Its tests have tremendous power over the lives of young people by stamping some of them 'qualified' and others 'less qualified'. (p. 1)

McClelland clearly views psychological test formats as instruments of power-power not just in a traditional political sense, but really as instruments with an impact on the course of individual lives. I'll return to this point again somewhat later. With a view towards the introductory sentences of the competency paper, it is sufficient at present to note that McClelland is raising — quite classically - the question of the legitimation of power: "Why should intelligence or aptitude tests have all this power? What justifies the use of such tests in selecting applicants for college entrance or jobs?" (p. 1).

On this ground, McClelland isn't questioning the general viability of psychological tests as an instrument for identifying suitable applications for schools and companies. He's questioning, quite forcefully, the role of intelligence tests as suitable tools for this specific process. He cites a variety of examples of how the current tests are biased in favor of specific social strata because they require the mastery of certain idioms most 
frequently found in the white upper middle class. During this same period, other authors such as Pierre Bourdieu (1978) or Michel Tort (1974) were questioning the validity of psychological tests as an overall instrument. Unlike them, however, McClelland can be understood as an exemplary proponent of a psychology-based critique of psychology. From his perspective, the questioning of the legitimacy of the current selection process could be reduced down to the question of whether the specific tests in use were valid: "The key issue is obviously the validity of so-called intelligence tests. Their use could not be justified unless they were valid" (1973, p. 1).

For advocates of intelligence tests, the validity of their procedures was confirmed explicitly through the direct correlation between the test results and the school grades of the test subjects. McClelland however rejects this criterion as worthless, since even the very first intelligence tests used by Alfred Binet and Théodore Simon drew on patterns from school instruction. As such, the structural similarity between school examinations and intelligence tests could still be observed in the follow-up models developed by Lewis Terman and his colleagues. The fact that students who performed well in intelligence tests also frequently had good grades can be attributed very simply to the fact that they were strong at a specific test format-without any firm indicators about their subsequent potential success in life. In McClelland's view this was a self-perpetuating cycle that ensured an established "meritocracy" of their claim to social privileges. He cites a series of studies that show that good school grades are no effective predictor of career success and writes of the results of these studies:

They make it abundantly clear that the testing movement is in grave danger of perpetuating a mythological meritocracy in which none of the measures of merit bears significant demonstrable validity with respect to any measures outside the charmed circle. Psychologists used to say as a kind of 'in' joke that intelligence is what the intelligence tests measure. That seems to be uncomfortably near the whole truth and nothing but the truth. (p. 2)

The normative background upon which McClelland bases this finding is the demand for social equality. As such, the first half of his paper takes on the character of a political manifesto. The fact that many psychologists are not interested in the question of whether political interests also play a role in the selection of test criteria is shown in McClelland's view to be dangerous naiveté (p. 4). Black applicants who failed the hiring tests because their "word game skills" were not equal to those of the white applicants are, for him, nothing less than "victims of oppression" (p. 6). The use of never-ending new studies that never leave the "charmed circle" to simply confirm the established practices is to McClelland's mind not just scientifically unsound, but also-above all else_-"socially irresponsible" (p. 5).

McClelland's critique is thus particularly focused on the element of standard testing practice which he has denoted as the fundamental dogma of the established "testing movement": the thesis that intelligence is an innate disposition that can be tested but not trained.

The mutual affirmation that arises from the symbiosis of intelligence and school testing itself already gives the process in question a circular form that always produces identical results. Yet it is the addition of this thesis of innate intelligence that truly gives the character of an immutable preordainment of our chances in life. In McClelland's view this precludes the possibility that an agency such as Educational Testing Service could provide a "genuine service," as the dominant "innate intelligence philosophy" turns every compatibility test into a "sentencing procedure" (p. 13).

\section{Second Normative Principle: Need for Achievement}

As already noted, McClelland's objections to intelligence tests follow the pattern of a psychology-based 
criticism of psychology. He is not interested in a fundamental criticism of the practice of psychological suitability testing, but rather in the weaknesses of a specific test format that should be replaced by a better format. The name of this better format: competency testing. "How would one test for competence, if I may use that word as a symbol for an alternative approach to traditional intelligence testing?” (p. 7).

The first characteristic of competency tests is that they test "a wider array of talents" documented in the form of a "profile" (p. 7). McClelland summarizes this move in the formula that competency-testing is not about "grades in school" but rather "grades in life" (p. 7). The new test formats should not only eliminate the discriminatory side effects inherent to the prior formats, but also work within a framework more true to life than the scenarios used in the intelligence tests. For this to work, one of the characteristic elements of traditional test formats — seen by McClelland as one of their greatest weaknesses - must be eliminated: the work with strongly pre-structured test situations that permit precisely one type of "correct" answer (p. 11). The attractiveness of such a procedure from the tester's perspective is clear; it increases the reliability of the test format and ensures that another observer will come to the same result at a different time. It brings with it however the great disadvantage that the test behavior (for example, playing word games) only has a very distant correlation with the behavior that the test subject is expected to show on the job (for example, being a good policeman) (p. 9). McClelland's emphatic use of the term life signalizes in this context a decisive expansion of the scope of testing. His answer to the proponents of the classic test formats is: "Life simply is not that structured" (p. 11).

In terms of the problematic explored by my paper, it is of key importance that the term of "life" used by McClelland to expand the potential scope of inquiry for psychology-based test formats is actually very narrowly defined in terms of its semantic content. In short, the "life" he's referring to here is "professional life." From start to finish, McClelland is equating "success in life" with "vocational success," "successful careers," etc. (p. 2).

This is not a mere linguistic coincidence, but rather an intentional terminological decision, as is clearly seen by a quick review of the implicitly normative background to McClelland's competency paper: The Achieving Society (McClelland, 1961). In this context I'd like to draw the attention to only one crucial point. The phrase "life" that appears in the second half of the competency paper and sets the benchmark for the evaluation of psychology-based test formats corresponds very clearly to the specific form of the Protestant work ethic that Max Weber analyzes in his famous essay The Protestant Ethic and the Spirit of Capitalism (Weber, 1988a). Weber's picture of the protestant work ethics serves McClelland in The Achieving Society as the model for a personality profile for motivated test subjects. Weber famously attempts to show how the Christian conceptualization of "Berufung" (avocation) gradually transforms into the concept of the "Beruf" (vocation) that is now so familiar to us. In the process, he attributes Calvinism and the Protestant sects - especially the Baptists, Mennonites, and Quakers - a central role in the formation of a modern work ethic. In light of this, it is of more than just biographical interest to note that McClelland was a Quaker. His concept of "life" didn't just happen to correspond with Max Weber's image of the ascetic, proto-capitalist life style, it is intended to correspond to it (cf. McClelland, 1961, Chp. II).

At the forefront of the research program for The Achieving Society stands a normative problem that didn't originate in the 18th but in the 19th century: not the core question of the Enlightenment regarding freedom and social equality, but rather the entrepreneur's question as to the most effective way to motivate the worker, whose labor he has purchased for the price of wages. This problem is described in the current sociology of 
labor and industry as a "transformation problem." The term refers to Marx who points out that while it is possible to sell labor as a good, the buyer nevertheless upon signing the employment contract does not yet have anything in hand (Marx, 1988, p. 188). The ability to work is not necessarily followed by the motivation to do so. The spectrum of potential obstacles ranges from simple fatigue to organized strike. Max Weber sums up the problem with the laconic formulation that workers, especially when they can join together as a group to establish a joint rhythm, tend to "slow things down" (Weber, 1988b, p. 35). The major question that has continually reappeared since then without ever really being resolved: how can it be ensured that the labor force available within a national economy is actually put to work? This classic problem is essential to understanding the intensity of research that has been done on the problem of motivation over the course of the 20th century.

The Achieving Society is among the most ambitious attempts in the field of motivation psychology. The book's starting thesis is that economic growth can be traced back to psychological factors and that among these factors, one is ultimately of decisive importance: the need for Achievement ( $n$ Achievement). I cannot go into details here on the test formats that McClelland and his staff developed to measure $n$ achievement. In short, they combine Freud's insight that motivations for action cannot be reduced to rational decisions with the claims of experimental psychology to provide quantifiable measurements for psychic phenomena. The most prominent product of these efforts is a systematic deployment of the Thematic Apperception Test (TAT), which uses images to stimulate free association of thoughts on which the test subject produces short stories that can be evaluated using a strictly coded procedure.

Whether it is actually possible to measure the motivation to achieve from such methods would be a different discussion. What is certain is that McClelland believes in this supposition and that this conviction flows directly into his sketch of the competency concept. His argument against strongly pre-structured test situations with pre-defined response options-in McClelland's terminology: respondent measures-draws directly on his review of the motif of achievement as he depicts it in The Achieving Society. The use of TAT and other similar formats allows, in McClelland's view, the deployment of operant measures that come closer to the open structure of life than the traditional respondent measures:

The $n$ Achievement measure, which is an operant in the sense that the subject emits responses (tells stories) under only very vague instructions, has predicted over a 12-14-year period in three different samples those who will drift into entrepreneurial business occupations. Here an operant is predicting an operant - the tendency to think spontaneously about doing better all the time predicts a series of spontaneous acts over time which leads the individual into an entrepreneurial occupation. (1973, p. 11)

That McClelland at this point takes the preference for entrepreneurship as his example is in and of itself not particularly meaningful. At other points he selects examples from the classroom or talks about hiring tests for police officers. Nevertheless it is justifiable to represent the thesis that the competency paper represents a direct continuation of the The Achieving Society. The entire argumentation of the text follows the basic premise that it is not just existing abilities that must be measured, but rather the improvement of aptitudes. McClelland's major interest in educational questions is, from the start, an interest in the potential of educating for better achievement. This is why Weber's study on the Protestant Ethic holds such a central position in his contemplation of the desire to achieve. In Weber, McClelland finds the thesis that an achievement-oriented attitude towards life can be traced back to specific forms of - in this case: religious - education.

As such, McClelland is naturally tracing a decidedly selective — not to say: bizarre - reading of Weber's Essay. Weber analyzes religious forms of lifestyles in a strictly descriptive way and closes his considerations 
with several dark comments about the "steely cage" of the capitalist culture. McClelland by contrast takes Weber's study as an instruction manual for successful life choices and uses him to derive a role model for "highs" (subjects with high $n$ Achievement score). In this regard, he also quotes a long passage from Calvin's Institutio Christianae Religionis centered on constant self-improvement, with the comment: "Calvin's description of what Weber calls 'rationalization' of life is written in terms of striving continually for perfection, which would be scored very high for $n$ Achievement" (McClelland 1961, p. 49).

These few comments will have to suffice for now. It is however hopefully clear that McClelland's polemic against the theory of innate intelligence is, in light of this background, put into an entirely different framework than in the first half of his essay. It's not social inequality that concerns him here, but rather education used to promote a motivation to achieve, which is blocked by the "innate intelligence philosophy." McClelland's thesis that all human abilities can be trained makes it possible to posit educational progress as a precondition for economical progress and to situate personal growth as a key prerequisite for economical growth.

The well advised teacher who heeds the lessons of psychology thus ascends to a key figure in the capitalist economic model—which brings us to the present.

\section{Weinert's Competency Concept and the Klieme Study}

Franz E. Weinert's definition of "competency" counts among the commonly cited texts in the current discussion of the problems associated with competency measurement and development. The remaining pages of his essay on "Measuring Achievement in Schools" are less frequently quoted, yet deserve the same careful attention, because Weinert very openly shares McClelland's conviction that economic growth can ultimately be attributed to psychological factors. He writes:

Even if questions about the relationship between a country's average educational levels and its economic prosperity continue to suffer from major empirical and theoretical deficits when run through an international comparison, all available data nevertheless speaks to a strong influence of various educational indicators on economic development [...]. To this extent the "human capital" factor plays an important role in the more modern macro- and microeconomic models. (2001, p. $26)^{2}$

Weinert's adaption of the competency concept for the educational field is consistently focused on the relationship between school education and an economic ability to achieve. His well-known definition of the competency theme pays homage to the proposal of the OECD "to replace the ambiguous understanding of achievement with the concept of competency" (p. 27). The definition itself wholeheartedly emphasizes the ability "to solve problems," and furthermore promotes "the motivational, volitional and social readiness and ability to apply the problem solution in variable situations, successfully and responsibly" as well (p. 27-8). It thus is not only a matter of "aptitudes," but rather of "motivation." Potential labor is useless without the desire to deploy it.

Weinert's definition of competency also enters in this form into the Zur Entwicklung nationaler Bildungsstandards, an expert report issued by a working group under the leadership of Eckhard Klieme on behalf of the German Ministry for Education and Research (2003).

\footnotetext{
${ }^{2}$ Auch wenn bei der Frage nach den Zusammenhängen zwischen dem durchschnittlichen Bildungsniveau eines Landes und seiner ökonomischen Prosperität im internationalen Vergleich noch große Empirie- und Theoriedefizite bestehen, so sprechen doch alle verfügbaren Daten für einen starken Einfluss verschiedener Bildungsindikatoren auf die wirtschaftliche Entwicklung [...]. Insofern spielt der Faktor ,Humankapital ‘ in den neueren makroökonomischen und mikroökonomischen Modellen eine wichtige Rolle.
} 
But it's not enough to determine that both of these influential texts merely maintain contact with the second half of McClelland's concept by limiting aptitude and motivation — and in particular motivation-for professional achievement closely to the outlook for economic growth. They also introduce a series of new elements into the discourse. Conclusively I mention only two of these new elements.

\section{First New Element: The Question of Responsibility}

Weinert's determination that the interest of the academic research into education "is shifting increasingly from the level of the school system and school organization to the level of the individual school" (2001, p. 22) is put in the context of a comprehensive reform project whose inception moment was actually an international failure: the significantly poorer-than-expected performance of the German school system in the TIMSS study (pp. 19-21). This then led to the question of apportioning blame or, as Weinert formulates it, "the question of pedagogical accountability and with it responsibility for successes and failures, for deficiencies and excellence, for strengths and weaknesses in the performance of schools and students" (p. 22). In this context, there is a heightened focus on reviewing "factors in instruction," whereby questions about the "qualification of the teachers" (p. 23) come to the forefront, meaning in effect that responsibility for success and failure is attributed not to the system, but primarily at the players within it. As such, McClelland's thesis is being carried consistently to its logical conclusion. If economic growth can be attributed back to mental factors and these mental factors are products of education, then the responsibility for the economic welfare of a country can be largely attributed to its educators. As such the Klieme study emphasizes "the responsibility of the schools and their instructors for educational performance" (2003, p. 49).

\section{Second New Element: The Production of Personality Traits}

The attempt to make schools and teachers responsible for the "educational performance" of students faces the criticism that the results in question here — namely: test results — at least initially are instructive solely for their implications of the aptitude of the student, not of the instructor. This is anything but a trivial observation, as schools face the same phenomenon as the workplace: students, like workers, can "slow things down" for any number of reasons. Yet the authors of the Klieme study do not just presume that one can distill aptitude and motivation for achievement from students' test results, they go on to interpret these abilities and motivation as "products" of teacher behavior.

At its core, the output of the education system encompasses not just the issuance of certificates, but also the establishment of competencies, qualifications, structures of knowledge, attitudes, convictions, and value systems - in short, the personality traits of the pupils that lay the groundwork for a lifetime of learning for personal improvement and societal engagement $(2003 \text {, p. } 12)^{3}$

Boiled down, the message is:

The output of the educational system encompasses [...] the establishment $[\ldots]$ of personality traits in the pupils.

The point of this extraordinarily simplistic production model of education-education produces personality traits - consists primarily in the fact that it allows for teachers to be evaluated based on the same

\footnotetext{
${ }^{3}$ Der Output von Bildungssystemen umfasst neben der Vergabe von Zertifikaten im Wesentlichen den Aufbau von Kompetenzen, Qualifikationen, Wissensstrukturen, Einstellungen, Überzeugungen, Werthaltungen—also von Persönlichkeitsmerkmalen bei den Schülerinnen und Schülern, mit denen die Basis für ein lebenslanges Lernen zur persönlichen Weiterentwicklung und gesellschaftlichen Beteiligung gelegt ist.
} 
model that has long been found in industrial environments, known in Germany as the "neue Leistungspolitik" (cf. Dröge et al., 2008).

The most important effect of this policy is that the achievements of employees are no longer measured based on the amount of labor invested, but rather by the market success of the product being produced. This method shifts the sole ownership of risk associated with the unpredictability of the markets away from the corporation itself by tying worker remuneration to achievement to the employees. If this concept for educational standards establishes itself permanently, then a similar dynamic can be applied to teachers. The shift to competency orientation allows for the performance of instructors to be assessed based on the model of the "neuen Leistungspolitik" and to ascribe to them the personality traits of their pupils as a product of their instruction. In the end, however, the behavior that will purportedly be interpreted into personality traits via psychological testing may well be as unpredictable as the economic cycles on world markets.

\section{References}

Bourdieu, P. (1978). Le racisme de l'intelligence. Cahiers Droit et Liberté, 382, 67-71.

Dröge, K., Marrs, K., \& Menz, W. (Eds.). (2008). Rückkehr der Leistungsfrage. Leistung in Arbeit, Unternehmen und Gesellschaft. Berlin: Edition sigma.

Gelhard, A. (2012). Kritik der Kompetenz (2nd ed.). Zürich/Berlin: Diaphanes.

Klieme, E., Avenarius, H.; Blum, W.; Döbrich, P.; Gruber, H.; Prenzel, M.; Reiss, K.; Riquats, K.; Rost, J.; Tenorth, H.-E.; Vollmer, H. J. (2003). Zur Entwicklung nationaler Bildungsstandards. Bonn/Berlin: German Ministry for Education and Research.

Marx, K. (1988). Das Kapital. Kritik der politischen Ökonomie. Berlin: Dietz.

McClelland, D. C. (1961). The Achieving Society. Princeton et al.: Martino Fine Books.

McClelland, D. C. (1973). Testing for competence rather than for intelligence. American Psychologist, 28, 1-14.

Tort, M. (1974). Le quotient intellectual. Paris: Petite Collection Maspero.

Weber, M. (1988a). Die protestantische Ethik und der Geist des Kapitalismus. Gesammelte Aufsätze zur Religionssoziologie, 17-206.

Weber, M. (1988b). Methodologische Einleitung für die Erhebung des Vereins für Sozialpolitik über Auslese und Anpassung (Berufswahl und Berufsschicksal) der Arbeiterschaft der geschlossenen Großindustrie. Weber, Aufsätze zur Soziologie und Sozialpolitik, 1-60.

Weinert, F. E. (2001). Vergleichende Leistungsmessung in Schulen-eine umstrittene Selbstverständlichkeit. In Weinert (Ed.), Leistungsmessung in Schulen (pp. 17-31). Weinheim/Basel: Beltz. 